\title{
DETERMINATION OF THE BEST INTEREST OF UNACCOMPANIED MINORS IN SLOVENIA'
}

\author{
Tjaša ŽAKELJ', Blaž LENARČIČ"
}

COBISS 1.01

\begin{abstract}
Determination of the Best Interest of Unaccompanied Minors in Slovenia

The paper deals with underage "third-country" nationals or stateless persons without parents or a legal representative, referred to as unaccompanied minors (UAMs). In Slovenia UAMs may hold varied types of status, and each of these implies different legal provisions and practical determination of the best interest of the child. According to the UNHCR Convention on the Rights of the Child, the best interest of the child should be the primary consideration in all actions concerning children. This paper focuses on how the principle of the best interest of the child is included in the sectoral national legislation and in other formal regulations which determine procedures regarding and treatment of UAMs. In addition, the article examines how experts understand this principle and put it into practice in various formal procedures. To that end, the views of experts who adopt or implement legal provisions, as well as the views of the experts who support UAMs during the international protection application process and in their everyday lives will be examined.
\end{abstract}

KEY WORDS: unaccompanied minors, best interest of the child, migrations, children

\section{IZVLEČEK}

Določanje najboljših koristi mladoletnih migrantov brez spremstva v Sloveniji

Članek se ukvarja z mladoletniki brez spremstva, to je z mladoletniki, ki so v pravni terminologiji opredeljeni kot mladoletni državljani tretjih držav in so na območju Slovenije sami, brez staršev ali zakonitega zastopnika. V Sloveniji imajo mladoletni migranti brez spremstva različne statuse, med katerimi vsak vsebuje različne zakonske določbe ter praktične določitve otrokovih najboljših koristi, ki naj bi bile usklajene s Konvencijo OZN o otrokovih pravicah. Članek ponuja tudi pregled vključevanja načela otrokovih najboljših koristi v nacionalno zakonodajo in druge formalne predpise, ki določajo postopke in obravnave omenjenih skupin otrok. Obenem obravnava način sprejemanja zakonskih ukrepov, njihovega izvajanja ali nadzorovanja ter kako strokovnjaki v različnih formalnih postopkih razumejo in določajo načelo najboljše koristi otroka.

KLJUČNE BESEDE: mladoletni migranti brez spremstva, otrokova najboljša korist, migracije, otroci

1 The study referred to in the paper is a part of the international project "In Whose Best Interests? Exploring Unaccompanied Minors' Rights through the Lens of Migration and Asylum Processes", carried out in 2014-2015 and financed by the EU. The project addressed the inclusion of the best interest of the child concept in legislation and best interest determination in the reception, protection and status procedures concerning UAMs in Austria (Universität Wien, Institut für Politikwissenschaft), France (Centre national de la recherche scientifique), the UK (University of Brighton) and Slovenia (University of Primorska, Science and Research Centre, IRSSV, Slovene Philanthropy). $\mathrm{PhD}$ in Sociology, Research Fellow; University of Primorska, Science and Research Centre, Garibaldijeva 1, SI-6000 Koper; tjasa.zakelj@zrs.upr.si

\| PhD in Sociology, Research Fellow; University of Primorska, Science and Research Centre, Garibaldijeva 1, SI-6000 Koper; blaz.lenarcic@zrs.upr.si 


\section{INTRODUCTION}

At a time when the European Union is facing the consequences of extensive migration flows, questions arise regarding the wellbeing of migrants and the support mechanisms of various states. In this paper we do not question the inclusion of human rights principles in international conventions (such as the European Convention on Human Rights or the Convention on the Rights of the Child) within the national legal provisions; our main focus is the implementation of these rights and the crucial principles of these conventions in practice. The paper deals with the general level of the implementation of the best interest of the child principle (BIC) as the key principle of official actions and decisions affecting children's lives, which is derived from the United Nations' Convention on the Rights of the Child (CRC) adopted in 1989. Based on the CRC principles, EU migration and asylum policy also sets out special provisions for unaccompanied minors (UAMs) as a vulnerable group of migrants and integrates BIC into numerous directives, ${ }^{2}$ which also focus on procedures concerning UAMs. While the abovementioned directives are legally binding for all member states, there is a certain leeway as to how the rules are adopted.

From the point of view of most migrants, Slovenia is a transition state. This means that most UAMs leave the country relatively quickly and follow their path to the countries of Western and Northern Europe (Slovene Philanthropy, PIC 2009). Data obtained by the Ministry of the Interior show that in the period from 2002 to the middle of 2016, 679 UAMs applied for international protection status. Seventy-three per cent of them (495) left Slovenia on their own, which means the international protection procedures initiated in all those cases were suspended. In a 15-year period, subsidiary protection status or refugee status was granted to 33 UAMs who applied for international protection. Meanwhile, data on whether the UAM was granted subsidiary protection status or refugee status is not available. Among UAMs who applied for international protection over the last five years, the majority are boys from Afghanistan and Syria.

Taking into consideration the situation in Slovenia, the paper addresses two perspectives of the inclusion of the BIC principle in procedures concerning UAMs. The first is the inclusion of the BIC principle in Slovenian legislation which determines the reception, protection and status procedures regarding UAMs; the second is an analysis of the inclusion of the BIC principle and its determination in procedures based on the opinions of experts who deal with UAMs, or in other words, the implementation of the BIC principle in practice. ${ }^{3}$

2 The directives are discussed in the next chapter.

3 The most significant gaps in the Slovenian mechanism which fail to provide proper care and support to UAMs are described in the paper 'The implementation of unaccompanied minors' rights in Slovenia: An analysis based on the best interest of the child principle" (Žakelj et al. 2015). If we speak in terms of Boylan's concept of basic human rights (2012) of UAMs, many are being continuously violated in Slovenia (Žakelj et al. 2015). 


\section{BIC AS THE KEY PRINCIPLE UNDERLYING OFFICIAL ACTIONS AND DECISIONS AFFECTING CHILDREN'S LIVES}

The BIC is one of the core principles of the CRC. ${ }^{4}$ Slovenia became a signatory to the CRC in 1991, and numerous measures to protect children's rights were subsequently adopted, e.g. the Resolution on the Foundations of the Formulation of Family Policy in the Republic of Slovenia, new legislation which regulated the entire education system, new health and social legislation and several other measures related to the implementation of the civil, political, social and economic rights of children.

The right of the child to have his/her best interests assessed and taken into account as a primary consideration in all actions or decisions that concern him/her, in both the public and private sphere, is set out in Article 3 of the CRC. Since the ratification of the Convention, its basic BIC principle has been expounded and elaborated upon in several UN documents and has also been included in relevant EU action plans and directives which focus on procedures regarding UAMs. Crucial documents will be mentioned which stress the use of the BIC principle in actions concerning UAMs or which address guidelines on how to determine BIC in practice. These documents are:

UNICEF's Implementation Handbook for the Convention on the Rights of the Child (published in 1998 and amended several times up to 2007). The last edition of the Handbook provides a detailed reference for the implementation of law, policy and practice to promote and protect the rights of children.

Comments of the Committee on the Rights of the Child: especially General Comment No. 6 (2005: 38) on how to determine BIC; on allowing the child access to territory, how to carry out assessment processes and regarding the appointment of a competent guardian and General Comment No. 14 (2013: 4) which defines the BIC as a three-fold concept; namely a substantive right, a legal principle and rules of procedure.

UNHCR Guidelines on Determining the Best Interests of the Child (2008) identify the underlying principles that can be used to construct a framework for ensuring compliance with the CRC in a formal best interest determination (BID). This document sets out legal and other principles that guide decision-makers in (1) making formal BIDs; (2) deciding who should act and what procedural safeguards BIDs should follow and (3) how criteria should be applied in order to take the best decision in a particular case.

UNHCR Field Handbook for the Implementation of UNHCR BID Guidelines (2011) offers additional advice on how to carry out the BID process in practice.

4 The principle of the best interest of the child as the crucial general principle along with the three main principles of the UNCRC emphasising children's rights to protection, provision and participation cause an ambiguity which complicates the implementation of the Convention through regulations and legislation (Kallio 2012: 82). On the other hand, the rights emphasised by the UN follow Western conceptions of a proper childhood (op. cit. 89), thus the UNCRC is often criticised as following a hegemonic understanding of childhood. Most in academia stress the need for a culturally sensitive approach to the understanding of childhood and would argue that UAMs are a typical example of such need. The question arises of whether a "culturally sensitive approach" would indeed enable a better response to the needs of UAMs or whether it would broaden the gap in standards of protection for native and other children, which is the current practice in Slovenia (Sedmak et al. 2017). 
UNHCR's and UNICEF's joint publication Safe and Sound: what States can do to ensure respect for the best interests of unaccompanied and separated children in Europe (2014), which aims to support states in the EU and EFTA in applying the BIC principle as a primary consideration when dealing with unaccompanied and separated children within their territory.

Specific provisions on UAMs and the inclusion of the BIC principle in procedures concerning UAMs are also guided by relevant EU documents such as:

Council Directive on the Right to Family Reunification (2003/86/EC), which aims to establish common rules of law relating to the right to family reunification.

Return Directive (2008/115/EU), which sets common standards and defines procedures for returning third-country nationals staying illegally in a Member State territory, determines exceptions, and includes provisions for children.

EU Action plan on unaccompanied minors 2010-2014 (COM (2010) 213 final), which identifies the need for comprehensive child protection systems as one of the elements of preventive action and elaborates upon the main course of action: prevention, regional protection programmes, reception and identification of durable solutions.

Reception Conditions Directive (2013/33/EU), which sets standards for conditions of the detention of (unaccompanied) children and access to education; provides rules on the protection of physical and mental health; requires Member States to take into account age-specific concerns and to ensure adequate living standards, and provides rules for the placement and tracking down the families of UAMs. The directive addresses some guidelines for assessing the BIC as well.

Asylum Procedures Directive (2013/32/EU), which establishes common standards of the asylum procedure with the aim to foster efficient and fair asylum decisions and sets common quality standards that also include special provisions for children.

Regulation (EU) 604/2013, which determines the EU Member State responsible for reviewing applications from asylum seekers in search of international protection, calls for close cooperation of Member States and for taking appropriate action to identify the family members, siblings or relatives of the UAM in the territory of Member States, whilst safe-guarding the BIC.

The above-listed UN and EU documents do not really establish specific care procedures for UAMs within national contexts, nor do they establish their rights. Instead, they include some specific provisions for UAMs, usually taking into account their vulnerability.

\section{THE BEST INTEREST OF UAMS IN SLOVENIA: LEGAL PROVISIONS AND THEIR PRACTICAL DETERMINATION}

A qualitative analysis was implemented in order to examine the inclusion of the BIC concept in national legislation and BID in practice. A careful examination of the main national acts and regulations ${ }^{5}$ was conducted in order to determine the inclusion of the BIC in

5 Act Amending the International Protection Act (ZMZ-D) (2013); Aliens Act (ZTuj-2) (2011); International Protection Act (ZMZ-UPB2) (2011); Marriage and Family Relations Act (ZZZDRUPB1) $(2004,2007)$. 
legal provisions concerning UAMs. The analysis of the determination of the best interest of the UAM in practice is based on semi-structured interviews with experts working in the field of protection of UAMs. The following subchapters will firstly provide data obtained from the analysis, highlighting the level of inclusion of the BIC principle in legal provisions concerning UAMs, and secondly will provide answers regarding how BIC is determined in practice, who the key players are in its determination and what obstacles are met in its practical implementation.

\section{UAMs and BIC in Slovenian legislation}

The most significant legal acts in Slovenia, which deals with the rights, statuses and obligations of UAMs are the Aliens Act (AA) and the International Protection Act (IPA). The first version of the AA was adopted in 2011 and amended several times (most recently in April 2014). It sets out the conditions for and methods of aliens' entry into, departure from and residence in Slovenia. UAMs who have not yet applied for refugee or subsidiary protection status or those who decide not to apply are dealt with under the AA and placed in the Aliens Centre near the town of Postojna, where they live in "a restricted movement area" which in practice means they are detained. ${ }^{6}$ Taking into consideration the BIC principle, an analysis of the AA demonstrates that this principle is not fully integrated within the AA. For instance, Article 82 of the AA stipulates that the police shall issue the UAM with a return decision if his/her special case guardian establishes that this is in his/her best interests, having carefully considered all the circumstances. This is the only mention of the $\mathrm{BIC}$ principle in the AA.

In the event that a UAM decides to apply for international protection (this possibility is presented to them by the special case guardian appointed by a local Centre for Social Work) he is transferred to the Asylum Home in Ljubljana and dealt with under the IPA.? The IPA came into force at the beginning of 2008 in order to regulate the international protection system in Slovenia on the basis of the Common European Asylum System. The IPA sets out the basic principles, the procedures for the granting and removal of international protection, the duration and the extent of international protection, the rights and obligations of applicants for international protection and those who have obtained international protection status, i.e. refugee status or subsidiary protection status. The IPA defines both refugee status and subsidiary protection status. According to Article 2, refugee status is granted to third country nationals who, owing to a well-founded fear of being persecuted for reasons of race, religion, national affiliation, membership of a particular social group or

6 The detention of children at the Aliens Centre is rarely disputed, while this issue is regarded as extremely relevant worldwide (see Global Campaign to End Immigration Detention of Children 2012; Gross, Song 2016). Slovenia is one of the EU countries that unfortunately does not provide an alternative to detention (Bloomfield 2015). Despite being generally overlooked, during periods with a more significant number of UAMs and other immigrants, NGOs and the Ombudsman's office stress the unacceptably long periods which children (with or without families) spend detained at the Aliens Centre. Such criticisms are ignored on the basis of the argument that there are no other available options.

7 The new IPA was adopted in 2016. In addition to other changes, it now stipulates that the duration of the procedure can be prolonged for an additional 9 months. 
political opinion, are outside their country of origin and are unable or, owing to such fear, unwilling to avail themselves of the protection of that country, or stateless persons who are outside the country of their former habitual residence as a result of such events and are unable or, owing to such fear, unwilling to return to it. At the same time, the IPA (Article 2) allows for the granting of the status of a subsidiary form of protection to third country nationals or stateless persons who do not qualify for refugee status in the case that there are substantive grounds for suspecting that upon their return to the country of origin (or in case of stateless persons, the country of last residence) the person would face a real risk of being subject to serious harm (such as the death penalty or execution, torture or inhumane or degrading treatment or punishment, serious and individual threats to a civilian's life or person by reason of indiscriminate violence in situations of international or internal armed conflict). The IPA stipulates that the BIC principle must be taken into consideration in proceedings in which the applicant is a UAM.

Even if BIC is a legal standard derived from general national legislation on child protection, there is a lack of guidelines on how it should be determined. BIC must be established in each particular case, taking into account specific circumstances. It is important to stress that the Slovenian legal provisions which serve as the legal underpinning for certain procedures regarding UAMs (the appointment of a legal representative or guardian) use the phrase/term interest of the child and not best interest of the child. The interest of the child is explicitly mentioned in several national laws, e.g. the Marriage and Family Relations Act and the Civil Procedure Act. As previously noted, there is no explanation as to what the phrase/term interest of the child actually means. For example, Article 4 of the Marriage and Family Relations Act, which is used for guardianship, implies that the interest of the child should be obtained by assuring conditions for healthy growth, coherent personal development and competences for the autonomous life and work of the child; Article 5 of the same act stipulates that in all activities and procedures affecting a child, parents, other persons, state authorities and bearers of public authority must act in the child's interest, and Article 6 stipulates that it is in the interest of the child to develop in a healthy manner. Similarly, the Civil Procedure Act (Article 408) explicitly requires the court to protect the interest of the child in legal and parental lawsuits ex officio.

Based on the findings presented here, it can be concluded that BIC cannot be pre-determined through the application of general regulations. Instead it must be specifically identified in each case when deciding on the children's rights and/or obligations. Any detailed regulation or definition of the child's best interest would therefore be turned into its opposite - narrowing it down to its understanding in the search for signs of preset definitions. 


\section{Best interest determination in practice}

This subchapter is dedicated to the analysis of interviews conducted with the experts working in the field. :? The selection of experts was made on the basis of several criteria: scope of duties; involvement in different procedures; involvement in formal or informal support to UAMs; experience in providing legal advice to UAMs; authorisation for the supervision of the implementation of human/children's rights; involvement in the daily lives of UAMs accommodated at official facilities. The main topics that will be further examined are: who the key players are in determining BIC in the context of UAMs; how the BIC is determined in procedures regarding UAMs; how the BIC can be realised in practice; the identification of crucial obstacles for individual BID; implementation of UAMs' right to actively participate in the procedure and identification of particularities in the system in response to the rights and needs of UAMs.

\section{Key procedures and actors determining the best interest of UAMs}

Documented UAMs in Slovenia have two possibilities, namely (1) to remain in the country as illegal migrants without status, accommodated at the Aliens Centre until they are returned to their country of origin, or (2) to apply for international protection and wait for a decision which has three possible outcomes: refugee status, which is more permanent in nature; subsidiary protection, which is extremely temporary in nature, or having their application refused on grounds of failure to meet the conditions for international protection. At the beginning of the international protection procedure, UAMs are accommodated at the Asylum Home. One special case guardian, who is in contact with all the UAMs staying at the Aliens Centre, noted that majority of minors choose the second option and consequently face complex and often long procedures to potentially obtain international protection status.

When they arrive in Slovenia, most UAMs come in contact with the border police, which searches for illegal migrants. Here it is important to stress that Slovenia has signed

8 In the period from 21 January to 14 April 2015, 13 semi-structured interviews were conducted with 14 experts: three representatives of NGOs (two from Slovene Philanthropy, the only organisation in Slovenia that systematically deals with assistance, advocacy and protection of UAMs, and one representative from the Legal Information Centre for NGOs, which offers legal counselling and information regarding laws on foreigners and international protection); one representative from the Aliens Centre; one representative of Ministry of the Interior (working in the field of integration), a special case guardian responsible for protection of UAMs accommodated in the Aliens Centre, one representative from the Asylum Home, one representative from the Border Police Division, one Deputy Ombudsman and a Senior Adviser, one representative of Ministry of Work, Family, Social Affairs and Equal Opportunities, two representatives from Centres for Social Work (one who works in an intervention service which offers exceptional support to foreign minors detected in Croatian border areas; the other who takes decisions on legal representatives for UAMs when applying for international protection status) and one legal representative of UAMs. All of the excerpts from interviews used in this paper were translated from Slovenian into English by the authors. 
several bilateral agreements ${ }^{<?>}$ which outline the return of persons who do not comply with conditions for entry to the state or stay in its territory. When the conditions for return are met, UAMs are sent back to the state they left before arriving in Slovenia. A representative from the Border Police Division had this to say when asked how it is possible to return UAMs to a state they had passed through considering their rights and the BIC principle:

In fact, it does not enter into our minds that Croatia could return them somewhere where their rights could be violated. Why? Because the principle of non-refoulement applies to us and so it applies to the Croats. And this is about the principle of trust in the legal order and the standards of an EU state. (Border Police Division Representative)

According to the interviews with experts who provide various means of support to UAMs, we have less information regarding procedures which take place at the borders.

[....] Border procedures are also very problematic, how they are treated at the border, what is happening there [....]. (NGO Representative 1)

Border procedures are more problematic in my opinion. They can be degrading, invade privacy, fail to respect their rights. [....] Such culture still prevails at the borders - that the one who is in control feels strong, and how they act towards foreigners, especially third country foreigners and not only UAMs, stems from their feelings of strength. (Deputy Ombudsman)

One interesting fact which speaks for itself is that border procedures regarding UAMs have not yet been observed or systematically researched. As our literature and data review revealed, similar to the other EU member states, in Slovenia there are no complete statistical records of the number of UAMs who have been permitted or refused entry into the country in recent years.

If not returned to the state they crossed on the basis of bilateral agreements, or in the event that the UAM has not (yet) asked for international protection by the police, he $e^{<?>}$ is taken to the Aliens Centre. On the basis of the AA, a special case guardian ${ }^{<?>}$ is appointed to him by the regional Centre for Social Work. The special case guardian conducts a conversation with the UAM in an attempt to identify what is in his best interest. The special

9 At the core of the Common European Asylum System established by the European Union (EU) is the right to asylum and the prohibition of refoulement, as guaranteed by the Charter of Fundamental Rights and the 1951 Geneva Convention Relating to the Status of Refugees and its 1967 Protocol. Both instruments are binding on EU Member States, which must also comply with the case law of the European Court of Human Rights (ECHR).

10 Since more than $90 \%$ of UAMs in Slovenia are boys, we will henceforth refer to UAMs using masculine pronouns.

11 Various terms are used to describe guardians in Slovenia. The terms differ depending on the procedure that applies to the UAM. In the case of the removal of an UAM who is, according to the law, unlawfully residing in the Republic of Slovenia, the Police must inform the Centre for Social Work, which has to immediately appoint a special case guardian for the child. UAMs who apply for international protection status are appointed a legal representative while a guardian in the usual sense of the word is appointed to children whose asylum procedure has been completed and who have been granted international protection (Slovene Philanthropy 2013: 17). 
case guardian interviewed here believes that in most cases in this first step it is of great importance that UAMs apply for international protection status.

My suggestion to them is based on the fact they are underage. I defend the view they should decide to apply for asylum. If they are granted asylum the list of their rights is much more extensive. (Special Case Guardian)

Upon the submission of the application for international protection and while waiting for the "final decision", UAMs obtain the rights of applicants (Articles 78 and 79 of the IPA). These rights include residence in the Republic of Slovenia, supply of materials in the event of accommodation at the Asylum Home or its branches (housing, food, clothing and toiletries), financial assistance in the event that private accommodation is found, education, access to the labour market and pocket money. These rights are well embedded in the national legislation, but as research by Žakelj et al. (2015) has revealed, they are often not adequately implemented in practice.

UAMs who decide to apply for international protection status are transferred to the Asylum Home, and a legal representative is appointed to them within 24 hours. According to the opinions of the majority of the experts interviewed, the role of legal representative is the most important in determining the best interest of each UAM. ${ }^{12}$

I would say the best interest of the child determination depends on the engagement of the legal representative. The legal representative is the one who is closest to the UAM. It depends how he/ she is appointed to the case. And how the best interest of the child and his will is recognised and taken into consideration in the procedure also depends on this. (NGO Representative 3)

The legal representative essentially protects the UAM's right to be heard in matters relating to him. In their duties toward the UAM, the legal representative protects his or her interests by taking into account the ethnic, linguistic, religious and educational background of the child. At the same time, when making decisions, the representative considers the minor's opinions and desires as far as possible in order to meet the child's best interest. As our expert interviews revealed, however, UAMs do not have the opportunity to actively participate in the process, as they are not asked for their opinions nor are their wishes listened to, particularly not at the beginning of the procedures.

Later, yes $[\ldots]$ He is the person who says what he wants, where to integrate him, which school he would like to attend, which sports he would like to participate in, or if he wants to become a get a library card [...] (Asylum Home Representative)

The role of the legal representative is limited to the support of UAMs during the procedure of obtaining status. If either refugee or subsidiary status is granted to the UAM, he is appointed a guardian. The fact that interviewees in our research stressed the role of the legal representative (and not the role of guardian) shows two relevant facts - first is the

12 Slovenia recently started training legal representatives for UAMs. The first generation of legal representatives started their work in June 2014, and the list currently includes two years (approx. 40) of trained legal representatives with various professional backgrounds. The legal representative is appointed to the UAM by the regional Centre for Social Work. 
temporary nature of the solutions and provisions for BIC, and the second is correlated to the fact that most UAMs in Slovenia receive support from a legal representative and only a few receive support from a guardian. This is because the procedure ends sooner if the UAM continues their journey to other EU countries or if no status is granted to them. Here we can see that the role of the legal representative is stressed, even if guardians who take care of UAMs with status have at least an equally important role to play.

\section{Determination of BIC and its realisation}

According to the UNHCR and UNICEF, the BIC principle should be embedded in the national structures and procedures by ensuring a holistic approach in order to establish a child's best interests. This means that the processes are above all child-friendly. "But implementation of the best interests of the child is subject to contradictory pressures such as migration control versus human rights for all irrespective of their nationality" (Lundberg 2011: 50). Our research among experts identified another important issue in the process of determination of the BIC principle in Slovenia, namely that it is in the hands of various individuals who are each responsible for one part of the procedure. "Each time it (BIC) is determined by the person who is in charge, individually for each part of the procedure" (Deputy Ombudsman).

From this quotation it is evident that in Slovenia, BIC depends mainly on the actors involved in the prescribed procedures. Furthermore, its implementation depends to a large extent on the personal endeavours of those involved in the process. To make things even more complex, the powers of those involved are greatly dispersed.

As I said, in relation to UAMs our tasks are very clear and narrow. This is a fact-finding procedure and appointment of a legal representative from the list of legal representatives. It is not a very wide range of tasks. (Centre for Social Work Representative)

An analysis of the national legislation (Žakelj et al. 2015) revealed that the dispersion of power relates to all actors involved in various procedures concerning UAMs. This can be seen by listing their roles. For example, a special case guardian is limited to one conversation at the Aliens Centre and advising on potential applications for international protection status or on the decision to be returned, while the legal representative's role is to take care of a list of tasks such as application for international protection, health issues, social issues, education, etc.

Our interviewees also revealed negative practises that are based on the prescribed characteristics of the process. One such example is the procedure surrounding the application for international protection status. This must be conducted within 24 hours of arriving at the Asylum Home and also includes an interview in the presence of four people unknown to the UAM.

We found this [procedure] very problematic because it happens right away, that is a few hours after the arrival at the Asylum Home. It is not necessary that UAMs are previously accommodated at the Aliens Centre, as in some cases they are sent directly to the Asylum Home [...] and the submission of the application is of vital importance because it is the basis for decision making 
regarding the protection status [...]. Imagine a child who might have travelled for months, who is hungry, not to mention his psychical condition and traumas, and he is sent into a room with people who he is seeing for the first time. The first person is the legal representative, who tries to explain to him that he/she is on his side, then there is a legal adviser, an interpreter and an official. And they try to convince him to tell his story of why he applied for international protection status. And I find this system totally inadequate; there is no time and place to prepare a child for such an important thing as the submission of the application. (NGO Representative 1)

Another example of the issues within the process stems from a characteristic of the legislation according to which UAMs are not treated as a party to the proceedings.

In all cases of appointing legal representatives we need to act according to the General Administrative Procedure Act. [...] And here there is a huge gap, because all the provisions for child protection are implemented in litigation procedures and actions, but it is not included in the general administrative procedure, which means that the child is not regarded as a party to the proceedings and he does not have these rights, neither procedural rights nor material rights. (Centre for Social Work Representative)

Additionally, the experts interviewed recognised the process of BID as an extremely complex process that depends on each individual case and must take into consideration several factors related to the child's circumstances (e.g. health condition, safety, past experiences, desires, expectations, aspirations, etc.).

It is not possible to speak about it [what is in the best interest of an individual UAM] in general terms. Each case is different. The best interest of the child can only be defined on the basis of all the information. It is of vital importance to acquire as much information as possible - why this child left his country, what is the main reason he left, where are his parents, where is he headed, was he travelling with someone, was he at risk when travelling, what are his plans and wishes and what were his parents' wishes, did his parents send him away or did he decide to go on his own? And this absolutely is not a matter of one meeting. [...] (NGO Representative 1)

I just know that we're working hard to find some sort of individual solutions even in some cases where it may be said that they are "tailor-made". Of course, I'm now talking about these minors who have been in our country for a long time, who stay in Slovenia and do not go further with their cousin to Sweden from the moment they are released from the Aliens Centre. (Border Police Division Representative)

Consequently the determination of the best interest of the child and its practical implementation in Slovenia is very difficult. This also evident from the opinions of the experts, who appear quite critical in their comments on the possibilities of applying the BIC principle in practice.

Even when you find out what would be in the best interest of a child you can't implement it, because the system does not allow it. I mean, there is no system. A child-friendly system that would enable child-friendly involvement in social welfare, health care, schooling, etc. does not exist in Slovenia. [...]. (NGO Representative 1) 
It's difficult. Not only in this field but in general. The best interest of the child is an excellent rule which can be interpreted in one way or another, but it is hard to achieve. [...] (Deputy Ombudsman)

At this point it should be noted that BID cannot be fully implemented for at least two significant reasons: (1) there are several authorised individuals in charge of the various decisions in a large number of procedural steps, and (2) too many people are involved in the whole procedure. In the majority of cases, BID is often only partial and recognised as such only by the specific authority responsible for one single step in the procedure.

\section{Treated as (indigenous) children?}

In our interviews we also asked experts about the suitability of these procedures with regard to adjustments which take into consideration the child as a special participant in the procedure. Their answers revealed not only that the procedures are not suitable for this particular vulnerable group of children, but also that authorities would not allow Slovenian children to go through the procedural problems that UAMs routinely experience.

[...] these individuals are principally considered as foreigners and not as children, which is evident from the understanding of these issues by the Ministry for Work, Family, Social Affairs and Equal Opportunities [with regard to] how much it is ready to help in practice. But the protection of this group of children is not recognised as their primary role. (Deputy Ombudsman)

[...] It was interesting to me that the list of trained legal representatives includes a lawyer who has worked at one of the centres for social work for years. And I remember sitting next to her at a training course. She said that the state would not allow a Slovenian child to go through what UAMs have to go through (from procedures and unclear responsibilities to being at risk, and the state does not do anything). (NGO Representative 1)

The rights of minor citizens and unaccompanied minors should be equal in theory and practice. Unfortunately the division between "us" and "them" is (still) omnipresent and results in the perception that "they are children, but not our children". This is clearly evident from the aforementioned expert statements which highlight that although the national legislation recognises UAMs as children with special protection and rights, in practice they are treated as aliens and not first as children. To make things even more difficult, in the majority of cases UAMs are subjected to procedures which would be never acceptable for indigenous children. It is important to note the attitude that should be the main criteria of the treatment UAMs, as presented in the interview with the representative from the Ministry of the Interior: "I think that if everyone gave a little thought, 'if that was my child' they would probably take a different approach" (Ministry of the Interior Representative). 


\section{Individual endeavours and the lack of a systemic response}

As Slovenia houses only a small number of UAMs who do not leave the state, we cannot claim that those who do stay are left without substantial support. This support, however, is mostly based on the informal endeavours of NGOs engaged in caring for UAMs. One of these is Slovene Philanthropy, which provides substantial support to new legal representatives who want to do what they believe is the best for the minors they represent. The main problem is that Slovenia has no systematic approach to the support of UAMs.

I believe the Slovenian reality is that every step is a part of an individual approach; there is no systematic approach. The problem with the Slovenian system is that there are some individuals (one person in particular) - from Ministry of the Interior, Slovene Philanthropy representatives, representatives of NGOs, volunteers - who do their best for the well-being of this group of children. The problem is that there is no system. [...] and when these individuals are no longer there, it will be much worse. [...] (NGO Representative 1)

It can be said that there is a lack of clarity in the tasks of those involved, and a lack of options for solutions (especially regarding accommodation, etc.). As is evident from the interview with the legal representative, legislation should not be an obstacle regarding representation of UAMs:

They (authorised bodies) all think they are limited by the legal regulations. I do not say we should act outside the law, but inside the law there are possibilities to do a lot. If there is the will. But everyone says: "This is not within our powers, we can't do it!" Come on, read it again, with all the commas and without the full stop at the end of the sentence. That's how I see it. (Legal Representative)

In addition, the procedure from the application submission onwards depends a great deal on the level of engagement of the legal representative:

I know a couple of legal representatives who give their best and do everything they can, sometimes they beat their heads against the wall so that minors get, I cannot say more than they are entitled to - this does not sound good, but they do get everything they need. (NGO Representative 2)

From the interviews conducted with the experts, it is evident that the individual engagement of the personnel involved (especially legal representatives with their knowledge and expertise, in combination with their commitment ${ }^{13}$ to their work) plays a crucial role in procedures involving UAMs. Since they carry out demanding tasks in support of UAMs, they must be supported with training and advice in order to do their work properly.

I am afraid my work is becoming routine for me. I think I could stand up for each individual more, go more often for a visit ... From one case to another. You might have some negative experiences, you become reluctant and you may be afraid (of not being successful). To overcome it, we need systematic supervision [...]. (Legal Representative)

13 Similarly, Jones (2001: 254) argues for the role of social workers in the UK system of support for unaccompanied minors. 
Such doubts present serious evidence of the fear of not being able to cope with the tasks necessary to determine BIC in each individual case. The numerous procedures some legal representatives are involved in, combined with the gaps in the system, lead them to become sceptical, which is based on not being supported by governmental authorities. Instead, the minimum level of care is encouraged, as all other options can only be realised on the basis of an intensive search for options which are not automatically available. The experience of not being supported discourages new endeavours for the full realisation of BIC.

\section{DISCUSSION}

Understanding the BIC principle through the lens of those procedures affecting UAMs confirmed the ambiguousness and subjectivity of the BID. As some authors (Aspinall, Watters 2010) argue, the legal recognition of the rights of UAMs does not guarantee their protection: the situation UAMs encounter in countries where they seek international protection embodies fundamental tensions between immigration policy and child welfare. The situation in Slovenia is specific in this regard. We can say that child welfare is at odds with immigration policy due to the fact that UAMs are recognised and treated as foreigners first. That they are under age and highly vulnerable is of secondary importance.

An analysis of the asylum procedures of Western countries (Cemlyn, Nye 2012) showed that the rights of UAMs can be undermined by reception arrangements and asylum processes which are not child-oriented, deficiencies in the availability and provision of services, and the likelihood of detention and removal. Based on the study at hand we can claim that the list of issues in Slovenia is quite similar. The first issue is the absence of systemic responses to the problem, which brings a significant burden to those who are willing to take on the role of active support for UAMs. In this regard, legal representatives (and later guardians when status is approved) can be looked upon as key workers who should strive to identify and realise the best interest of the UAMs who stay in Slovenia. Even though the system of trained legal representatives is in its infancy, some serious problems are already evident. For instance, only the most limited tasks of representation within procedures are paid, which may cause legal representatives to do only the minimum with regard to BIC. Although legal representatives receive significant informal support from Slovene Philanthropy, there is doubt that they will be willing to do this work long-term, as with no systemic changes, legal representatives and their informal supporters will face the same obstacles over and over again. We must stress that exercising the rights of UAMs cannot depend on the individual endeavours of the actors involved, as this places minors in an extremely unequal situation in comparison with other children.

Our analysis also showed that procedures involving UAMs are highly fragmented, so the BID depends on various individuals (border control, special case guardian, legal representative, decision maker, staff involved in potential age disputes, those deciding on request for transfer out of the Asylum Home, etc.). Such a fragmentation of the key actors involved in this principle offers too many options for treating an individual as just one among many applicants, with no emphasis on an integrated individual approach. The current situation calls for the joint training of all individual actors.

Finally, we should mention that the issues facing UAMs receive very little attention in Slovenia. There is not a great deal of discussion about this matter at scientific, political 
nor general levels. It can be concluded that their presence is seen and felt mostly by those who are involved with UAMs and meet them on a daily basis. Other issues which remain largely unaddressed are what happens at the border, how many UAMs are returned to other countries on the basis of bilateral agreements, and on what terms is it recognised that return is in their best interest. Unfortunately these questions cannot yet be answered due to a lack of comprehensive official national statistics. The same can be argued for the question regarding to what extent the principle of a durable solution is considered when authorities make decisions on the status of UAMs. There is much evidence which shows that durable solutions are not taken into consideration.

\section{REFERENCES}

Act Amending the International Protection Act (ZMZ-D) (2013). Official Gazette of the RS $111 / 13$.

Aliens Act (ZTuj-2) (2011). Official Gazette of the RS 50/11.

Aspinall, Peter, Watters, Charles (2010). Refugees and Asylum Seekers: A Review from an Equality and Human Rights Perspective. Equality and Human Rights Commission, http://www.equalityhumanrights.com/sites/default/files/documents/research/refugees_and_asylum_seekers_research_report.pdf (9. 5. 2016).

Bloomfield, Alice, Tsourdi, Evangelia, Pétin, Joanna, de Bruycker, Phillipe (eds.) (2015). 'Alternatives to Immigration and Asylum Detention in the EU: Time for Implementation', https://fluechtlingsdienst.diakonie.at/sites/default/files/fluechtlingsdienst/files/ madereal-report-_alternatives_to_detention_in_the_eu.pdf (19.10. 2016).

Boylan, Michael (2012). Dolžnosti do otrok. Časopis za kritiko znanosti, domišljijo in novo antropologijo 40/249, 53-66.

Cemlyn, Sarah Judith, Nye, Miriam (2012). Asylum seeker young people: Social work value conflicts in negotiating age assessment in the UK. International Social Work 55, 675-688.

Civil Procedure Act (ZPP) (1999). Official Gazette of the RS 73/07.

Committee on the Rights of the Child (2005). General Comment No. 6 on "Treatment of unaccompanied and separated children outside their country of origin", http://www2. ohchr.org/english/bodies/crc/docs/GC6.pdf (2. 8. 2015).

Council Directive 2003/86/EC of 22 September 2003 on the right to family reunification.

Directive 2008/115/EC of the European Parliament and of the Council of 16 December 2008 on common standards and procedures in Member States for returning illegally staying third-country nationals. Official Journal of the European Union L 348/98.

Directive 2013/32/EU of the European Parliament and of the Council of 26 June 2013 on common procedures for granting and withdrawing international protection. Official Journal of the European Union, L 180/60.

Directive 2013/33/EU of the European Parliament and of the Council of 26 June 2013 laying down standards for the reception of applicants for international protection. Official Journal of the European Union, L 180/96.

European Commission (2010). Action Plan on Unaccompanied Minors (20102014) (COM(2010) 213 final), http://eur-lex.europa.eu/LexUriServ/LexUriServ. do?uri=COM:2010:0213:FIN:en:PDF (2. 8. 2015). 
Gros, Hanna, Song, Yolanda (2016). "No Life for a Child": A Roadmap to End Immigration Detention of Children and Family Separation. Toronto: International Human Rights Program, University of Toronto Faculty of Law.

Hodgkin, Rachel, Newell, Peter (2007). Implementation Handbook for the Convention on the Rights of the Child. Fully revised third edition. Geneva: UNICEF, http://www. unicef.org/publications/files/Implementation_Handbook_for_the_Convention_on_ the_Rights_of_the_Child_Part_1_of_3.pdf (2.8.2015).

International Protection Act (ZMZ-UPB2), Official Gazette of RS 11/2011.

International Protection Act (ZMZ-UPB2) (2011). Official Gazette of the RS 11/2011.

International protection Act (ZMZ-1) (2016). Official Gazette of the RS 22/2016.

Jones, Adele (2001). Child Asylum Seekers and Refugees. Rights and Responsibilities. Journal of Social Work 1, 253-271.

Kallio Kirsi, Pauliina (2012): Desubjugating Childhoods by Listening to the Child's Voice and Childhoods at Play. An International E-Journal for Critical Geographies 11/1, 81-109.

Lundberg, Anna (2011). The Best Interests of the Child Principle in Swedish Asylum Cases: The Marginalization of Children's Rights. Journal of Human Rights Practice 3/1, 49-70.

Marriage and Family Relations Act (ZZZDR-UPB1) $(2004,2007)$. Official Gazette of the RS 69/04, 101/07.

Ministry of the Interior (2015). Poročilo $z$ delovnega področja migracij, mednarodne zaščite in vključevanja za leto 2014. Ljubljana: Ministrstvo za notranje zadeve.

Regulation (EU) No 604/2013 of the European Parliament and of the Council of 26 June 2013 establishing the criteria and mechanisms for determining the Member State responsible for examining an application for international protection lodged in one of the Member States by a third-country national or a stateless person. Official Journal of the European Union, L 180/31.

Sedmak, Mateja, Lenarčič, Blaž, Medarić, Zorana, Žakelj, Tjaša (2017). »Not our children«: Unaccompanied Minor Asylum Seekers in Slovenia. London: Routledge, forthcoming.

Slovene Philanthropy and Legal-Informational Centre for Non-Governmental Organizations - PIC (2009). Policies on reception, return, integration arrangements for, and numbers of, unaccompanied minors in the Republic of Slovenia.

Slovene Philanthropy (2013). Implementing the core standards for guardians of separated children in Europe, Country assessment: Slovenia.

UNHCR (1989). Convention on the Rights of the Child, http://www.un.org/ga/search/view_ doc.asp?symbol=A/RES/44/25 (30. 5. 2015).

UNHCR (2008). Guidelines on Determining the Best Interests of the Child. Geneva, http:// www.unhcr.org/protect/PROTECTION/4566b16b2.pdf (2. 8. 2015).

UNHCR (2011). Field Handbook for the Implementation of UNHCR BID Guidelines, http:// www.unhcr.org/50f6d27f9.html (23. 7. 2016).

UNHCR (2014). Safe and Sound: What States can do to ensure respect for the best interests of unaccompanied and separated children in Europe, http://www.refworld.org/docid/ 5423da264.html (13. 8. 2016).

Žakelj, Tjaša, Lenarčič, Blaž, Medarić, Zorana, Sedmak, Mateja (eds.) (2015). Implementation of unaccompanied minors' rights in Slovenia: An analysis based on the best interest of the child principle. A journey to the unknown: The rights of unaccompanied migrant children: Between theory and practice. Koper: Annales University Press, 42-99. 


\section{POVZETEK}

\section{DOLOČANJE NAJBOLJŠIH KORISTI MLADOLETNIH MIGRANTOV BREZ SPREMSTVA V SLOVENIJI \\ Tjaša ŽAKELJ, Blaž LENARČIČ}

V prvem delu članka avtorja predstavita koncept otrokovih najboljših koristi ter ključne evropske in preostale mednarodne dokumente, ki so podlaga $\mathrm{za}$ opredelitve omenjenega načela $v$ primerih obravnav mladoletnih migrantov brez spremstva. Sledi analiza slovenske zakonodaje, ki določa postopke v zvezi z mladoletnimi migranti brez spremstva. Cilj analize je ugotoviti, na kakšen način je načelo najboljše koristi otroka umeščeno v pravni okvir. Avtorja ugotavljata, da je v področni zakonodaji to načelo integrirano le do določene mere, nekoliko bolje v primerih postopkov prosilcev za mednarodno zaščito ali mladoletnikov, ki imajo enega od statusov mednarodne zaščite, in mnogo manj, ko govorimo o mladoletnikih, ki (še) niso obravnavani kot prosilci za mednarodno zaščito. V obeh primerih manjka celovitejša in natančnejša opredelitev, kako naj se načelo upošteva $\mathrm{v}$ praksi. V drugem delu so predstavljeni rezultati intervjujev s strokovnjaki, ki so udeleženi v obravnavo ali vsakdanje življenje mladoletnih migrantov brez spremstva. Rezultati so pokazali več relevantnih težav glede določanja najboljših koristi mladoletnih migrantov brez spremstva. Prvič, da je upoštevanje načela otrokove najboljše koristi običajno odvisno od osebe, ki otroka trenutno obravnava (npr. policist, odločevalec v postopku pridobivanja mednarodne zaščite, socialni delavec, zakoniti zastopnik ipd.); drugič, da je treba poudariti pomanjkljivosti trenutnega sistema delovanja zakonitih zastopnikov (npr. plačilo je omejeno zgolj na najosnovnejše naloge v postopku, kar posledično pomeni, da sistem spodbuja, da bi zakoniti zastopniki zagotavljali le najnujnejšo skrb za uresničevanje otrokovih pravic), navsezadnje pa, da so mladoletni migranti v postopkih obravnavani najprej kot tujci in šele potem kot otroci. Avtorja poudarjata tudi marginalnost obravnavane teme v slovenskem znanstvenem prostoru. 